\title{
On the interpretation of wh-clauses in exclamative environments ${ }^{*}$
}

\author{
Franz-Josef d'Avis \\ University of Lund \\ Franz-Josef.dAvis@tyska.lu.se
}

\section{Introduction}

In this paper, a class of sentences in German is discussed that are often called whexclamatives. Examples are in (1).

(1) a. Heinz ist erstaunt, wen Maria eingeladen hat.

Heinz is amazed who M. invited has

'Heinz is amazed who M. has invited.'

b. Heinz ist erstaunt, wie gross Maria ist.

'H. is amazed how tall M. is.'

c. Wen der alles eingeladen hat!

who he all invited has

'The people he has invited!'

d. Wie gross die ist!

how tall she is

'What is she tall!'

So called wh-exclamatives can be roughly characterized as wh-clauses that are embedded under exclamative predicates like erstaunt sein/to be amazed at, see $(1 \mathrm{a}, \mathrm{b})$, or that are used as the basis for an exclamation, see (1c, d). ${ }^{1}$

One can ask if wh-exclamatives are a clause-type of their own, in particular, whether they are different from wh-clauses in question environments, that is under question predicates ${ }^{2}$ like to ask or to wonder or used as questions. It is often assumed that wh-clauses in exclamative contexts, both embedded and unembedded, are indeed different from whclauses in interrogative or question environments like (2), at least regarding their semantical type, see for example Elliot (1971, 1974), Grimshaw (1979, 1981), Zaefferer (1983, 1984), Altmann (1987, 1993).

(2) a. Heinz fragt sich, wen Maria eingeladen hat.

$\mathrm{H}$. wonders who $\mathrm{M}$. invited has

'H. wonders who M. has invited.'

* The paper is submitted to a special issue of "Theoretical Linguistics", edited by Klaus von Heusinger and Kerstin Schwabe

1 On predicates that one would not consider to be exclamative, but which nevertheless embed wh-clauses like in (1) see below.

2 These are intensional predicates in the sense of Groenendijk/Stokhof (1982). 


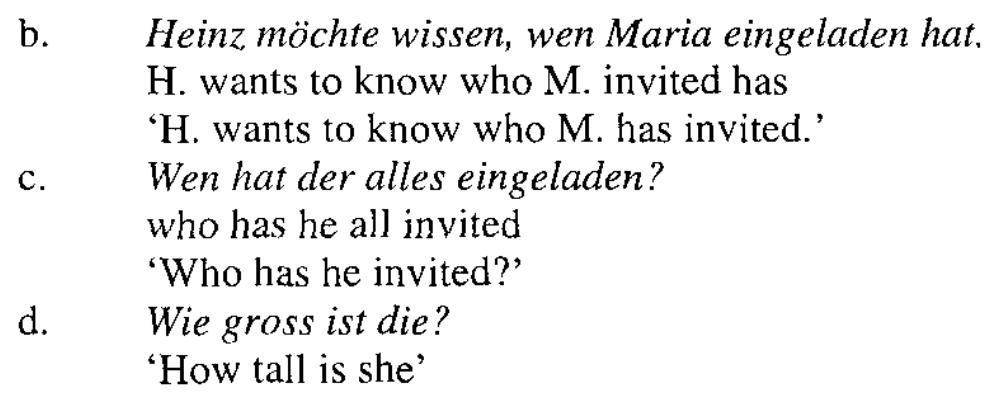

I assume with Grimshaw (1979) that so called wh-exclamatives and wh-interrogatives are alike with respect to their syntactical properties. In addition, I think that they are also alike semantically. So, what I like to do here is to evaluate the following hypothesis:

(H1) So-called wh-exclamatives are of the same semantical type as wh-interrogatives.

Regarding $\mathrm{H} 1$ the following points should be discussed:

(i) Why can certain wh-clauses be embedded under exclamative predicates but not under question predicates, see (3)?

(3) a. Heinz ist erstaunt, wie überaus groß Maria ist.

' $\mathrm{H}$. is amazed how very tall $\mathrm{M}$. is.'

b. $\quad$ *Heinz möchte wissen, wie überaus groß Maria ist.

$\mathrm{H}$. wants to know how very tall $\mathrm{M}$. is.

(ii) Why is it, that $o b$-clauses/whether-clauses are ungrammatical under exclamative predicates, but grammatical under question-predicates, see (4)?

(4) a. *Heinz ist erstaunt, ob Maria zu Hause ist.

$\mathrm{H}$. is amazed whether $\mathrm{M}$. is at home

b. Heinz möchte wissen, ob Maria zu Hause ist.

$\mathrm{H}$. wants to know whether $\mathrm{M}$. at home is

'H. wants to know whether M. is at home.'

(iii) Why are certain unembedded wh-clauses grammatical as Exclamations, but not as Questions, see (5)?

(5) a. Wie überaus groß sie ist!

how very tall she is

b. $\quad$ Wie überaus groß sie wohl ist?

how very tall she PART is

(iv) How can one explain the relation between wh-clauses and their interrogative meaning, and their use as exclamations. That is: how can one derive the expression of an emotional attitude to a given state of affairs with regard to certain unembedded w-clauses? 
I begin with describing the semantics of exclamative predicates and the way they interact with wh-complements, section 2 . In section 3 , I tackle the question in (i). Section 4 deals with the question why $o b$-clauses can not be embedded under exclamative predicates. In 5 it is shown how independent wh-clauses can be used as exclamations. A summary follows in 5 , including some remarks on the differences between the considerations here and those in Zanuttini/Portner (2000). ${ }^{3}$

\section{On the semantics of exclamative predicates}

The aim of this section is to describe the semantics of predicates like erstaunt sein/to be amazed at and the way they interact with the meaning of their wh-complements, eventually giving a characterization of the class of exclamative predicates.

Consider a sentence like (6).

(6) Heinz ist erstaunt, wen Maria geheiratet hat.

Heinz is amazed who Maria married has

'Heinz is amazed who Maria has married.'

Basically the matrix-predicate erstaunt sein/to be amazed at denotes a relation between the matrix subject and at least two propositions.

The first proposition describes the true state of affairs, that is the proposition 'that Maria married Heinz', if she married Heinz. The second proposition describes in this case what the matrix-subject expected to be the true answer to the wh-clause clause, for example, the proposition 'that Maria married Karl', if it was this Heinz expected to be the case.

I call that the norm-proposition, because it generally describes the matrix subject's idea of what counts as the norm regarding the answer to the embedded wh-clause.

I assume that a wh-clause denotes basically a set of propositions in the sense of Karttunen (1977).

So the meaning of (7) applied to the world $w$ is (8), the set of propositions of the form in (9), that are true in the world $w$, that is the set of propositions, so that there is a person $x$ and Maria has invited $x$ in $w$.

wen Maria eingeladen hat who Maria invited has

(8) $\quad \lambda p\left[\exists x \operatorname{pers}(x)(w) \& p=\lambda w^{\prime}\right.$. eingeladen $($ maria $\left.)(x)\left(w^{\prime}\right) \& p(w)\right]$

(9) $\quad \lambda w$. eingeladen $($ maria $)(x)(w)$

But the meaning in (8) is not strong enough, see for example Groenendijk/Stokhof 1982. Consider the example in (10)

3 In a broader perspective the paper can be seen to contribute to the research on sentences types, in particular to the question how many there are. If the hypothesis is correct, we could end up with one less. 
(10) Heinz weiß, wen Maria eingeladen hat. Heinz knows who Maria invited has 'Heinz knows who Maria has invited.'

If (10) is true, we want Heinz not only to know for all the people that Maria invited, that Maria invited them. We also want Heinz to know that these are all the people that Maria invited. That is Heinz should not have a wrong belief about someone else, who was not invited.

In this sense, the meaning in (8) is too weak. It makes not sure, that Heinz knows all the people Maria invited and only those.

Heim (1994) solves this problem with the introduction of two answer-concepts that can be seen as reflecting different aspects of the meaning of a wh-complement. The basic meaning of the wh-clause is not changed. It is still a Karttunen one. Different matrix predicates can refer to different aspects of the meaning of their wh-complement.

The answer concepts are in (11) and (12).

$$
\begin{aligned}
& \text { Answer } 1 \text { : } \\
& \text { ans } 1 \text { (wh-clause, } w)=\leftrightarrow[[\text { wh-clause }]](w)
\end{aligned}
$$

The answerl to a wh-clause in the world $w$ is the intersection of the intension of the whclause applied to world $w$. That is the proposition that can be expressed by the conjunction of all the answers to the wh-clause that are true in the world w.

Answer2:

ans $2($ wh-clause,$w)=\lambda w^{\prime}\left[\right.$ ans $1\left(\right.$ wh-clause,$\left.w^{\prime}\right)=\operatorname{ans} 1($ wh-clause,$\left.w)\right]$

The answer2 to a wh-clause in the world $w$ is the set of worlds where the answer 1 to the wh-clause is the same as in the world $w$. That is the proposition that the true answers are the true answers.

Answer2 expresses the strong exhaustive meaning we need for the relation between matrix predicates like wissen/to know and their wh-complement.

But where do we need the concept answer1? One case Heim mentions is given by exclamative predicates like to be amazed at.

The norm-proposition I mentioned above, that is the proposition the matrix subject expected in sentences like (13), is derived from the negation of the answerl.

Consider a sentence like (13).

(13) Heinz ist erstaunt, wer gekommen ist.

Heinz is amazed who come is

'Heinz is amazed at who came.'

If Heinz is amazed who came, he expected another answer to the wh-clause to be true that stands somehow in a relation to the true answer and he expected the true answer to be false. But the expected answer is not just the negation of answer 2 .

Suppose, Maria and Peter came. The negation of the proposition that Maria and Peter are the only persons that came, is the complement set of the set of worlds, where Maria and 
Peter came and only these two. The complement set is here the set of worlds, where the set of people that came is different. But a world where Maria, Peter and Paul came is also different from the real world.

Suppose, Heinz had expected that Maria, Peter and Paul came. Could he really be amazed, if only Maria and Peter came. That is, could (13) be true with respect to this state of affairs? The seems to be not the case, cf. also Berman (1994).

The answerl to the wh-clause in (13) is the set worlds where all persons came that came in the real world. The complement set is the set of worlds, where not all persons came, that came in the real world. Particularly the world, where Maria, Peter and Paul came is not in the complement set of the answer1.

So, we can think a predicate as erstaunt sein/to be amazed at with a wh-complement to relate the matrix subject in the following way to two propositions, one being the answer 2 to the wh-clause and one being the negation of the answer1, see (14).

(14) If Heinz is amazed at who came, he knows: answer2(who came)

and he had expected: $\neg$ answerl (who came).

A problem is that, if someone came, a world where none came is also in the negation of the answer 1 .

But I don't think that (15a) is true, if Heinz expected that none came.

(15) a. Heinz ist erstaunt, wer gekommen ist.

Heinz is amazed who come is

b. Heinz ist erstaunt, daß (überhaupt) jemand gekommen ist.

Heinz is amazed that (anyway) someone come is

'Heinz is amazed that someone came at all.'

In a case where Heinz expected none to come, (15b) seems to be appropriate.

My point here is, that the proposition that is expected must be a subset of the negation of the answerl. It must be a set of worlds, where the extension of the meaning of the whclause is not empty. There must be an instantiation of the wh-variable.

The same is true for the true answer to the embedded wh-clause. Exclamative predicates require the wh-variable to be instantiated. The set of relevant propositions must not be empty.

Consider (16) and (17). While (16) can be true

Heinz, weiß, wen Maria eingeladen hat.

Heinz knows who M. invited has

even if Maria didn't invite anybody and Heinz knows exactly that, (17) can not be true in the case that Maria didn't invite anybody.

(17) Heinz ist erstaunt, wen Maria eingeladen hat.

Heinz is amazed who Maria invited has 
So, although both verbs are factive in the sense of Kiparsky/Kiparsky (1970) in that they presuppose the truth of the proposition of their that-complement, there are differences w.r.t. wh-complements. To know does not require the wh-variable to be instantiated, so the argument in (18) goes through, cf. Groenendijk/Stokhof (1982), that is from (18a) and (18b) follows (18c).

(18) a. Heinz knows who Maria has invited.

b. Maria did not invite anyone.

$-->\quad$ c. Heinz knows that Maria didn't invite anyone.

In the case of to be amazed at, a parallel argument is not correct, see (19).

(19) a. Heinz is amazed at who Maria has invited.

b. Maria did not invite anyone.

$-/>\quad$ c. Heinz is amazed that Maria didn't invite anyone.

I take it that it is presupposed that the wh-variable must be instantiated. This property is constant under negation, as it should be.
a. Heinz ist erstaunt, wen Maria geheiratet hat. Heinz is amazed who Maria married has.
b. Heinz ist nicht erstaunt, wen Maria geheiratet hat. Heinz is not amazed who Maria married has.

In both (20a) and (20b) the existence of a new husband is presupposed.

So, the here relevant properties of the class of exclamative predicates with wh-complements are the following:

(i) an exclamative predicate describes an emotional attitude to a state of affairs.

(ii) it is presupposed that the wh-variable is instantiated, i.e. it exists a positive answer.

(iii) we have an alternative proposition, the norm-proposition. The norm-proposition is derived from the answerl to the wh-clause in a systematic way, as a subset of the complement set of the answer1. It must also be a positive answer.

I assume that at least these two propositions are ordered on a scale in a way that the expected propositon is the one that sets the norm, and the true proposition is ordered at a distance that reflects the strength of the amazement. The stronger the matrix subjects amazement, the higher up on the scale is the true proposition. This property is also linked to the exclamative predicate and is not part of the meaning of the wh-clause itself.

That there is indeed an emotional attitude as part of the meaning of exclamative predicates is shown by the following consideration: There are predicates that explicitly express the non-existence of an emotional attitude towards a certain state of affairs like egal sein or nicht jucken/not care. Those predicates cannot cooccur with exclamative predicates, relating to the same state of affairs, see (21). ${ }^{4}$

4 See Fries (1988) for independent exclamatives. 
*Heinz ist erstaunt, wie überaus groß Maria ist, aber es ist ihm egal.

Heinz is amazed how very tall Maria is, but he is indifferent towards this.

The properties one usually associates with wh-exclamatives, that is expression of an emotional attitude, presupposition of the propositional content, ordering of at least two relevant propositions on a scale, follows in this view solely from the properties of the matrix predicates. What the wh-clause does is that it provides via its interrogative semantics the possibility to compute the relevant alternative propositions.

With exclamative predicates embedding a wh-clause, we have a relation between the matrix subject and two different propositions: one describing the true exhaustive answer to the wh-clause, the answer 2 in Heims terms, and one describing the norm-proposition.

\section{Special Wh-phrases}

\subsection{Data}

Now I turn to question (i) in the introduction: Why can certain wh-clauses be embedded under exclamative predicates but not under question predicates?

Consider the examples in (22) and (23).

(22) a. Heinz ist erstaunt, wie ïberaus groß Maria ist. Heinz is amazed how extremely tall M. is

b. Heinz ist verwundert, wie enorm breit der Eßstisch ist. Heinz is amazed how enormously broad the table is

c. Heinz ist verblifft, wie pfeilschnell der neue Wagen ist.

Heinz is stunned how arrow-fast the new car is

'Heinz is stunned how very fast the new car is.'

d. Heinz ist erstaunt, wie saukalt es heute ist.

Heinz is amazed how pig cold it today is.

'Heinz is amazed how extremely cold it is today.'

e. Heinz findet es erstaunlich, wie riesig Maria ist.

Heinz finds it amazing how gigantic M. is

(23) a. *Heinz fragt sich, wie überaus groß Maria ist. Heinz asks himself how extremely tall $M$. is

b. $\quad$ *Heinz möchte wissen, wie enorm breit der Eßtisch ist. Heinz wants to know how enormously broad the table is

c. *Heinz fragt sich, wie pfeilschnell der neue Wagen ist. Heinz asks himself how arrow-fast the new car is

d. $\quad$ *Heinz möchte wissen, wie saukalt es heute ist. Heinz wants to know how pigcold it today is

e. $\quad$ *Heinz fragt sich, wie riesig Maria ist. Heinz asks himself how gigantic $M$. is 
In (22) we have exclamative predicates embedding wh-clauses with a certain kind of whphrases. In the relevant reading, these wh-clauses are ungrammatical as complements of question predicates as in (23). ${ }^{5}$

It seems pretty obvious, which elements are responsible for the contrast in (22) and (23), at least regarding a. to $\mathrm{d}$. In the a- and b-cases we have intensifying elements (überaus and enorm) inside the adjective phrase, adverbials to the adjectives. Without these syntactical intensifiers, embedding under question-predicates is ok, see (24).
a. $\quad$ Heinz fragt sich, wie groß Maria ist.
Heinz wonders how tall $M$. is
b. $\quad$ Heinz möchte wissen, wie breit der Eßtisch ist.
Heinz wants to know how broad the table is

I call überaus etc. syntactical intensifiers in contrast to the intensifying elements in c. and d. that come into play by way of a morphological process. Other than syntactical intensifiers, they are not so free w.r.t. the adjectives they combine with.

But they are responsible for the ungrammaticality of $(23 \mathrm{c}, \mathrm{d})$. Without them the sentences are ok, see $(24 c, d)$.
c. Heinz fragt sich, wie schnell der neue Wagen ist.
Heinz wonders how fast the new car is
d. Heinz möchte wissen, wie kalt es heute ist.
Heinz wants to know how cold it today is

(23e) is not so obvious w.r.t. to the analysis of the adjective phrase. Riesig can be an adverbial as in (25).

(25) a. Heinz ist erstaunt, wie riesig groß der Dom ist.

Heinz is amazed how enormously big the dome is

In this case, it is in line with the syntactical intensifiers überaus and enorm, but the adjective gro $\beta$ had somehow to be deleted in $(22 \mathrm{e}$ and $23 \mathrm{e})$, if riesig was always an adverbial.

On the other hand, we can think of riesig in (22e and $23 \mathrm{e})$ indeed as an adjective. The intensifying element is somehow inherent to the adjective. riesig so means, what it means intuitively, namely sehr or riesig groß, that is: very or enormously big. The form of riesig without the inherent intensifying element is simply gro $\beta$, and gro $\beta$ is of course ok in a sentence like (23e), see (26).

(26) Heinz fragt sich, wie groß Maria ist.

Heinz wonders how tall Maria is

Before I come to the possible readings of the sentences in (23), there is some connected data, see (27) and (28).

5 I shall come back to the point of identifying the different readings. 
(27) a. Heinz ist erstaunt, welchen Bombenerfolg das neue Stück hatte. Heinz is amazed, which bomb-success the new piece had

b. Heinz findet es verblüffend, welche Bullenhitze im Kino herrscht. Heinz finds it stunning which bull-heat in the cinema reigns

c. Heinz ist verblüfft, welchen Affenzahn Maria draufhat. Heinz is stunned which monkeytooth Maria on it has

d. Heinz ist verwundert, welchen Bärenhunger Karl mitgebracht hat. Heinz is amazed which bear-hunger Karl with-brought has

(28) a. *Heinz fragt sich, welche Bullenhitze im Kino herrscht.

b. $\quad *$ Heinz möchte wissen, welchen Affenzahn Maria draufhat.

c. $\quad *$ Heinz wollte wissen, welchen Bombenerfolg das neue Stück hatte.

d. *Heinz will wissen, welchen Bärenhunger Karl mitgebracht hat.

(29) a. Heinz fragt sich, welche Temperatur heute im Kino herrscht. Heinz wonders which temperature today in the cinema is

b. Heinz möchte wissen, welches Tempo Maria am liebsten fährt. Heinz wants to know which speed Maria best of all drives

In this cases we are dealing with noun phrases that are intensifjed, either morphologically, like (27a,b and d) or inherently like (27c). Bomben is in these cases a prefix meaning something like enormous. Affenzahn means in this context high speed. ${ }^{6}$

If we can find a more neutral form for this intensified noun phrases, so to speak stripped off their intensified element, embedding under question predicates is ok, see for example (29a) for (28b) and (29b) for (28c). This is parallel to the cases with adjectives above.

The second relevant contrast concerns multiple wh-complements. Although they are grammatical under exclamative predicates, ${ }^{7}$ see (30), there are exceptions.

(30) a. Heinz ist erstaunt, wen Maria wo getroffen hat.

Heinz is amazed whom Maria where met has

'Heinz is amazed whom Maria met where.'

b. Heinz ist verblüff, wem Maria wann geholfen hat.

Heinz is stunned whom Maria when helped has

'Heinz is stunned whom Maria helped when.'

c. Heinz ist erstaunt, wie groß welcher Spieler ist.

Heinz is amazed how tall which player is

d. Heinz ist verblüff, wie breit welcher Fluß ist.

Heinz is stunned how broad which river is

With the adjective phrases I talked about above, multiple wh-clauses are not grammatical, see $(31){ }^{8}$

\footnotetext{
See Van Os (1989) on intendifiers.

7 Cf. also Karttunen (1977).

8 See also Lahiri (1991).
} 
(31) a. *Heinz ist verblüfft, wie überaus breit welcher Fluß ist. Heinz is stunned how extremely broad which river is

b. $\quad$ *Heinz findet es erstaunlich, wie pfeilschnell welcher Wagen ist. Heinz is amazed how very fast which car is

c. $\quad *$ Heinz ist erstaunt, wie riesig welcher Spieler ist. Heinz is amazed how extremely tall which player is

d. $\quad$ *Heinz ist verwundert, wie überaus groß welches Mädchen ist. Heinz is amazed how very tall which girl is

I will come back to these examples in connection with the solution to the contrast in (22) and (23). But now to the different reading of sentences as in (23).

\subsection{Possible Readings}

The two different readings of sentences like (22) and (23) can be identified in different contexts.

Lets take for example $(22 \mathrm{c}, \mathrm{e})$, repeated as $(32 \mathrm{a}, \mathrm{b})$.
a. Heinz findet es erstaunlich, wie riesig Maria ist. Heinz finds it amazing how gigantic M. is
b. Heinz ist verblüfft, wie pfeilschnell der neue Wagen ist. Heinz is stunned how arrow-fast the new car is

If we have a context as in (33a), that is: Heinz knew that Maria is gigantic, then Heinz is amazed at the degree to which Maria is gigantic.

(33) a. Heinz wußte, daß Maria riesig ist, aber er ist erstaunt, wie riesig sie ist. Heinz knew that Maria is gigantic, but he is amazed at how gigantic she is.

Call this the degree-reading.

In a context like (33b) it is not the degree Heinz is amazed at, but the fact that Maria is gigantic and not only tall or very tall.

b. $\quad$ Heinz wußte, daß Maria groß ist, aber er ist erstaunt, wie riesig sie ist. Heinz knew that Maria is tall, but he is amazed how gigantic she is.

It is not the degree to which Maria is gigantic that is amazing. It is taken for granted that someone that is gigantic is so to a certain degree. Call this the non-degree-reading.

It is the non-degree reading that is not available in a wh-clause embedded under a question predicate, see (34).

(34) a. Heinz wußte, daß Maria riesig ist, nun wollte er wissen, wie riesig sie ist. Heinz knew that Maria is gigantic, but now he wanted to know how gigantic she is. 
b. $\quad$ \#Heinz wußte, daß Maria groß ist, nun wollte er wissen, wie riesig sie ist. Heinz knew that Maria is tall, but now he wanted to know how gigantic she is.

With an adjective like pfeilschnell the degree-reading seems to be not available at all. So, sentences with wie pfeilschnell should be bad under question predicates. This is indeed the case, see (35).

*Heinz weiß, daß der Wagen pfeilschnell ist, nun will er wissen, wie pfeilschnell er ist.

Heinz knows that the car is very fast, now, he wants to know, how very fast it is.

With exclamative predicates the only available reading for clauses with wie pfeilschnell is the non-degree-reading, see (36a).

(36) a. Heinz, weiß, daß der Wagen schnell ist, aber er ist erstaunt, wie pfeilschnell er ist.

Heinz knows that the car is fast, but he is amazed how very fast it is

b. $\quad *$ Heinz weiß, daß der Wagen pfeilschnell ist, aber er ist erstaunt, wie pfeilschnell er ist.

Heinz knows that the car is very fast, but he is amazed how very fast it is

The intensifying elements, whether syntactical, morphological or inherent, refer to extreme areas on a scale related to the meaning of the adjective they belong to. These extreme areas can be very small. In the extreme case, these areas are so small, that a subdivision in different degrees is no longer possible, see also Rehbock (1997). This seems to be the case with pfeilschnell/as quick as lightning.

Another hint in the same direction is, that adjectives like pfeilschnell have no comparative form, so (37) is ungrammatical.

* Der gelbe Wagen ist pfeilschneller als der grüne.

The yellow car is more fast as lightning as the green one

Nonetheless, I am not sure if one should place these adjectives in the same class as nongradable adjectives like true or married, that are not possible at all in wie/how-phrases introducing a wh-clause.

The two different readings, the degree-reading and the non-degree-reading, have also effects on what I called above the norm-proposition. In the case of (38) with the predicate erstaunt sein it is the proposition describing Heinz' expectations.

(38) a. Heinz ist erstaunt, wie riesig Maria ist.

Heinz is amazed how gigantic $M$. is

b. degree-reading:

Heinz expected Maria to be gigantic to another degree. 
c. non-degree-reading:

Heinz expected Maria to be just tall or even of normal height, but not gigantic.

The interesting point w.r.t. the non-degree reading is, that Heinz didn't expect Maria to be riesig/gigantic at all.

The problem is now, how to derive the norm-proposition to the non-degree-reading if the norm proposition is actually another answer to the question how gigantic Maria is, that is an answer to the question to what degree Maria is gigantic.

\subsection{Paraphrases to the non-degree reading/ Appositions}

How can we paraphrase the non-degree-reading? I want to go back to some examples of Grimshaw (1979) that she used to show a difference between wh-clauses under exclamative predicates and under question predicates.

Question predicates allow only disjunctive appositions like Tom or Harry in (39a).

(39) a. John wondered who, Tom or Harry, had gone to the movies.

b. *John wondered who, (namely) Tom and Harry, had gone to the movies.

This kind of apposition to a wh-phrase has a certain effect: It is presupposed that the content of the apposition is the true instantiation of the wh-variable, that is: Tom or Harry had gone to the movies. If we assume an exclusive or, this means for (39a) that either Tom or Harry had gone to the movies.

The difference to a conjunctive apposition like in $(39 \mathrm{~b})$ is, that we still have a choice between Tom and Harry. Intuitively, it still makes sense, to ask about which one of the two constitutes the true instantiation of the wh-variable.

A conjunctive apposition on the other hand, or one with just one element, also presupposes that its content is the true instantiation of the wh-variable. But in theses cases there is no choice, and it doesn't seem to make sense to ask about it, see the German examples in $(40)$.

(40) a. *Heinz möchte wissen, wen Maria eingeladen hat, Karl und Gustav.

Heinz wants to know who, Karl and Gustav, Maria has invited.

b. *Heinz möchte wissen, wen Maria eingeladen hat, (nämlich) Karl.

Heinz wants to know who Maria has invited, (namely) Karl.

Under exclamative predicates, a conjunctive apposition or a one-element apposition is ok, see (41).

(41) a. Heinz ist erstaunt, wen Maria eingeladen hat, nämlich Karl und Gustav.

Heinz is amazed who Maria invited has, namely Karl and Gustav

b. Heinz ist erstaunt, wen Maria eingeladen hat, nämlich Karl.

Heinz is amazed who Maria invited has, namely Karl 
W.r.t. the wh-phrases with intensifying elements, I assume now that the intensifying elements are basically like the appositions in (41).

So we can paraphrase the non-degree-reading of the sentences in (42) as in (43).

a. Heinz ist verblüft, wie pfeilschnell der neue Wagen ist.

Heinz is stunned how arrow-fast the new car is

b. Heinz findet es erstaunlich, wie riesig Maria ist.

Heinz finds it amazing how gigantic M. is

(43) a. Heinz ist verblüfft, wie schnell (, nämlich pfeilschnell,) der neue Wagen ist (, nämlich pfeilschnell).

Heinz is stunned how fast (, namely fast as lightning,) the new car is (, namely fast as lightning).

b. $\quad$ Heinz findet es erstaunlich, wie groß (, nämlich riesig,) Maria ist (, nämlich riesig).

Heinz finds it amazing how tall (, namely enormously,) M. is (, namely enormously).

The effect of the apposition is the same as in the examples (39) - (41). It is presupposed that the element named in the apposition is the true instantiation of the wh-variable.

So, for example, in (43b) the question in the embedded wh-clause is actually not about how gigantic Maria is, but how tall she is, with the presupposition that she is enormously tall.

If the question in (43b) is, how tall Maria is, it is also possible to compute the right norm-proposition, the proposition, that was expected. We are not interested in different degrees to which Maria is tall, that is the expected proposition has nothing to with a certain degree, to which Maria is gigantic.

We are interested in the answers to the neutral question, how tall she is. And an answer here could well be that she is of normal height, or even small. By treating the intensifying element as an apposition with the mentioned properties, it is possible to derive the correct norm-proposition.

The presupposition of the intensifying elements can also be related to the speaker. This is shown by examples like (44).

(44) a. Heinz weiß nicht, wie überaus groß/riesig Maria ist ( $^{*}$, und ich auch nicht). Heinz knows not, how enormously tall/gigantic Maria is (* and I too not)

b. Heinz hat vergessen, welche Affenhitze im Kino herrschte (*, und ich auch). Heinz has forgotten which monkey-heat in the cinema reigned (* and I too)

c. Heinz weiß nicht, wie groß Maria ist (, und ich auch nicht). Heinz knows not how tall Maria is (, and I too not).

d. Heinz hat vergessen, welche Temperatur im Kino war (, und ich auch). Heinz has forgotten which temperature in the cinema reigned (* and I too)

In the cases where it is clear that the speaker doesn't know the answer to the embedded whclauses, the whole sentence becomes ungrammatical. That is, in the cases with intensifying 
elements. The neutral adjective or nominal forms as in (44c and d) are ok. That means, the speaker has to know the instantiation of the wh-variable.

The assumption, that the instantiation of the wh-variable named in the apposition is presupposed as the true answer to the wh-clause leads to a meaning of the wh-clause with just one possible answer: the one given in the wh-clause.

Exactly this is the reason why the non-degree reading is not possible in question environments like (23) above. It simply makes no sense to ask for something the answer to which is given in the question.

This is formulated in the restriction in (45).

(45) Wh-clauses that presuppose their only true answer are not allowed in question environments.

That does for example not exclude wh-clauses, that presuppose more than one true answer like (31a).

The contrast in (31) above, that the wh-phrases with intensifying elements are not grammatical in multiple wh-clauses can be explained, if we assume, that there must be more than one instantiation for each wh-variable in a multiple wh-clause, see for example Wachowicz (1974). The interpretation of the intensifying element as an apposition with the above named properties, excludes that there is more than one instantiation. So, a multiple wh-clause is not possible.

To sum up:

(i) W.r.t. the non-degree-reading, the intensifying elements are analyzed as a sort of apposition, triggering a certain (speaker-related) presupposition, that in turn leads to an interpretation with just one true answer, that is named in the apposition.

(ii) the norm-proposition is derived from the meaning of the wh-clause without the intensifying element.

(iii) the contrast in (22) and (23) is derived from the properties in (i) and the restriction in (45).

This answers basically question (i) of the introduction.

\section{4. $O b$-clauses}

In this section I discuss the question (ii) from the introduction, why $o b$-clauses are ungrammatical as complements of exclamative predicates, see (46).

a. $\quad$ *Heinz ist erstaunt, ob es regnet.

Heinz is amazed whether it is raining

If $o b$-clauses and wh-interrogatives have the same semantical type that is the basis for selectional properties of a matrix predicate, one must discuss why certain predicates select only for a subclass. This selectional peculiarities w.r.t. the class of interrogatives are in no way restricted to exclamative predicates. 
There are different classes of predicates that take only wh-interrogatives, or subclasses of wh-interrogatives, or only $o b$-clauses, or only subclasses of $o b$-clauses.

The communication verbs zugeben, gestehen, bekennen/admit take a wh-complement but are quite bad with $o b$-clauses, see (47). ${ }^{9}$

a. Heinz hat zugestanden/zugegeben/bekannt, mit wem er die Nacht verbracht hat.

Heinz has admitted with whom he the night spent has

'Heinz has admitted whom he spent the night with.'

b. ??Heinz hat zugestanden/zugegeben/bekannt, ob er die Nacht mit Maria verbracht hat.

Heinz has admitted whether he the night with Maria spent has

'Heinz has admitted whether he spent the night with Maria.'

This is also the case with verbs like schildern oder beschreiben/describe, see (48).

a Heinz schilderte/beschrieb mir, wo Peter wohnt.

Heinz described me where Peter lives

b. *Heinz schilderte/beschrieb mir, ob Peter in Hamburg wohnt.

Heinz described me whether Peter in Hamburg lives

Schwarz (1993) identifies a class a verbs he calls 'Verben der sequentiellen Abarbeitung' like runterrattern or aufzählen/to list that only take a subclass of wh-clauses as complements, see (49), and for which he formulates a condition that excludes the ungrammatical ones.

(49) a. *Maribel rattert herunter, welches Buch Carmen gelesen hat.

Maribel lists which book Carmen has read.

(=Schwarz 1993: (7a))

b. Maribel rattert herunter, welche Bücher/was Carmen gelesen hat.

Maribel lists what/which books Carmen has read.

Huddleston (1994) shows for predicates like bezweifeln/doubt, zweifelhaft sein/be doubtful, fraglich sein/be questionable that they are sensitive w.r.t. to the type of $o b$-clause they take as a complement. They are ungrammatical with alternative $o b$-clauses, see (50).

a. Ich bezweifle, ob Maria zu Hause ist.

I doubt whether Maria is at home.

b. $\quad$ Ich bezweifle, ob Maria zu Hause ist oder in der Kirche.

I doubt whether Maria is at home or in the church.

What this diverse data suggests is that we must try from case to case to find out the reasons for the semantical incompatibility between a class of predicates and a certain type of clause

9 Cf. Dipper (1997: fn. 45). 
in complement position. I will do that here for the class of exclamative predicates and $o b$ clauses.

Actually, it is not so self-evident, why a predicate like to be amazed should not go together with an $o b$-clause. If we consider for example a sentence with know like (51),

Heinz knows whether it is raining.

so is the intuition that Heinz knows that it is raining, if it is raining, and that Heinz knows that it is not raining, if it is not raining. Why can't we interpret a sentence like (52) in the same way?

$$
\text { *Heinz is amazed (at) whether it is raining. }
$$

That is: if it is raining, Heinz is amazed that it is raining, and if it is not raining, Heinz is amazed that it is not raining. As for the norm-proposition, Heinz could in each case easily have expected the opposite.

I think the relevant factor here is an element that exclamative predicates share with a broader class of predicates which are included in the class a emotive predicates Kiparsky/Kiparsky (1970: 363) characterize as "in general all predicates which express a subjective value of a proposition rather than knowledge about it or its truth value".

The important element is that we are dealing with an evaluation of a proposition. For an evaluation it seems to be basic to have the possibility of a relation to a relevant object of comparison. ${ }^{10}$ This object of comparison is w.r.t. exclamative predicates and the true answer the norm-proposition. It is the answer to the wh-clause that describes the matrix subject's idea of the norm. So, what an exclamative predicate requires of its complement is that there are two possible answers. And, as we have seen in section 2, not only two possible answers, but two positive, possible answers. The last point seems to be directly relevant for the problem with $o b$-clauses. In this case, we have in principle only one possible positive answer, so that we can formulate the following restriction on the relation between exclamative predicates and their wh-complements.

(53) A relation between an individual and a wh-complement, that is given by an exclamative predicate, is well defined only, if there are two possible positive answers to the wh-clause. ${ }^{11}$

With the restriction in (), we exclude $o b$-clauses as complements of exclamative predicates and have an intuitively reasonable answer to the question (ii) in the introduction.

10 Cf. Fries (1994) for the description of emotions as evaluations of state of affairs or objects relative to the physical an psychological needs of the person that expresses them.

"In d'Avis (2001:101) I have given a somewhat different restriction with a more technical counterpart. This is related to a modification of the Karttunen-semantics of $o b$-clauses I am discussing there. 


\section{Unembedded Wh-(exclamatives)}

The fourth question in the introduction was how we can relate unembedded wh-clauses with their interrogative meaning to their use as exclamations. Examples are given in (54). (Capitals stand for emphasis.)
a. Wen DIE geheiratet hat!
whom she married has
b. Wen DIE alles eingeladen hat! whom she all invited has
c. Wen hat DIE alles eingeladen! whom has she all invited
d. Wem DER alles geholfen hat! whom he all helped has
e. Wie RIESIG die ist!
how gigantic she is
f. Wie RIESIG ist die!
how gigantic is she

An exclamative utterance of the sentences in (54) expresses an emotional attitude of the speaker towards a certain state of affairs, that is not in accordance with his or her expectations. An exclamation on the basis of a wh-clause presupposes the propositional content of the wh-clause to be true.

An interesting point w.r.t. German is that the position of the finite verb does not differentiate between the uses as exclamations or questions. Both V2-clauses, see $(54 \mathrm{c}, \mathrm{f})$ and verb-final clauses can be used as exclamations.

I assume that exclamation is an element related to the use of language, see also Fries (1988) and Rosengren (1992, 1994, 1997). So, how can one imagine the relation between the interrogative meaning of a wh-clause and its use as an exclamation?

Constitutive for an Exclamation is an emotional attitude of the speaker to a state of affairs, that is presupposed to be true, and a difference between this state of affairs and the speakers idea of the norm.

The point that the expression of an emotional attitude is part of an exclamative illocution can be made clear with examples like (55) where the speaker at the same time tries to express that he is indifferent towards the relevant state of affairs.

a. Wie SCHÖN Maria ist! \#Aber das ist mir egal. How beautiful Maria is! \#But I don't mind.

The presupposed state of affairs is described by the answer 2 to the wh-clause, that is the true answer.

A Hearer expects the speaker to know the answer. Consider the exclamation in (56).

S1: Wen DIE geheiratet hat! whom Maria married has 
If die has married Heinz, then S1 should know, that she has married Heinz. This is at least what $\mathrm{S} 2$ thinks, if he replies (57).

\section{S2: Wen HAT Maria denn geheiratet? Whom did Maria PART marry}

If $\mathrm{S} 1$ does not know the true answer to the question in (57), the utterance of (56) as an exclamation is defective.

But the information that Maria married Heinz is not overtly part of the utterance. If the speaker knows the true answer, but holds it back, the relevance of the utterance must lie in something else. With respect to exclamations this could be interpreted in the following way: the relevant aspect is the expression of the speakers emotional attitude to the state of affairs that is described by the true answer.

The connection to the proposition that describes the speakers norm is as in the embedded case: the proposition is a subset of the negation of the answerl. For instance w.r.t. (56): S1 could consider it to be normal, that Maria married someone else.

But how do we know that the utterance is to be interpreted as an exclamation and not as a question?

The relevant factor is the obligatory exclamative accent, compare Rosengren (1994, 1997).

The exclamative accent is easy to tell apart from contrast accents or other focussing accents, see Altmann (1993). Its particular properties are greater maxima w.r.t. the basic frequency, greater length and possibly a higher intensity, cf. Oppenrieder (1987), (1989), Batliner (1988). ${ }^{12}$ The function of the exclamative accent is to show, that we are dealing with an expression of an emotional attitude. I assume, that emotions expressed by exclamations go together with an evaluation of the relevant state of affairs, see Fries (1994). An evaluation is possible, if there is an object of comparison. The relevant state of affairs is described by the true answer to the wh-clause. The object of comparison is the normproposition, derived from the negation of the answerl. Exclamative illocutions and exclamative predicates (with wh-clause) share some basic properties:

- the propositional content of the wh-clause is presupposed,

- an emotional attitude towards a state of affairs is expressed,

- two certain propositions are needed, that are compared with each other

- the first proposition is the true answer to the wh-clause

- the second, the norm-proposition, is derived form the complement set of the answer 1.

To exclude wh-clauses with intensifying elements like (58) from being used as a question, is actually not so hard now. These wh-clauses have the same properties as the embedded ones in that they presuppose their only true answer.

Wie ÜBERAUS GROSS die ist!

how enormously tall she is

12 For the connection between exclamative accent and emphatical accent w.r.t. declarative clauses see Wingert (1996), for discussion of the intonation inside the wh-phrase see Bötz (1995). 
And so they are subject to the restriction in (45), they are not allowed in question environments.

I have derived the exclamative illocution on the basis of a wh-clause through certain properties of emotions as part of the language system. These properties: existence of a certain state of affairs, evaluation part, derivation of an object of comparison are given by the function of the obligatory exclamative accent as the reflection of the emotional involvement of the speaker. The interrogative meaning of the wh-clause provides the set of propositions that are needed to compute the relevant norm-proposition.

\section{Summary}

The answers to question (i) and (iii) in the introduction are basically the same. Certain whclauses are excluded from question contexts because of the properties of the intensifying elements inside the clause-initial wh-phrase. W.r.t. question (ii), $o b$-clauses are excluded as complements of exclamative predicates, because they do not provide two possible positive answers. The answer to question (iv) uses the obligatoriness of the exclamative accent and some considerations on the properties of emotions expressed by linguistic utterances. Concerning these questions, I think the hypothesis in ( $\mathrm{Hl}$ ) can be maintained.

Before I finish, I have a few remarks on a paper by Raffaella Zanuttini and Paul Portner which Paul sent me after the DGfS-meeting in Leipzig. ${ }^{13} \mathrm{I}$ think that our considerations go in the same direction, though they differ in detail and w.r.t. the evaluation of the syntactical properties of wh-clauses in exclamative environments. As far as the German examples are concerned, there is in principle no syntactical difference between wh-clauses in exclamative environments and in question environments. The concept of widening that is introduced by Zanuttini/Portner (2000) captures the difference between the norm-proposition and the true answer to the wh-clause described here. In opposite to Zanuttini and Portner, I do not assume that there is a factive component as part of the relevant wh-clause. Factivity comes into play either by way of the interaction between the meaning of the wh-clause or as the outcome of the effect the exclamative accent has w.r.t. unembedded wh-clauses used as exclamations. The difference could become clear in examples with the matrix predicate wissen/know. Wissen takes ob-complements, see (59a) and also apparent exclamative complements, see (59b).
a. Heinz weiß, ob es regnet.
Heinz knows that it is raining.
b. Heinz weiß, wie überaus groß Maria ist.
Heinz knows how very tall Maria is.

In addition wissen takes wh-complements that could be interrogative or exclamative.

(60) Heinz weiß, wen Maria eingeladen hat.

Heinz knows, whom Maria has invited.

13 Zanuttini/Portner (2000). 
The embedded clause is possible with exclamative and question predicates. As far as I can see, an approach that distinguishes between exclamative and interrogative wh-complements would predict a systematical ambiguity in cases like (60). At least w.r.t. the German data, I can not see that an ambiguity arises. Nevertheless, taking into consideration that Zanuttini and Portner also deal with other languages, for instance Italian and Paduan, I think it could be worth a try to put the results of the two approaches together, to get a more general picture.

\section{References}

Altmann, H. (1987). Zur Problematik der Konstitution von Satzmodi als Formtypen. In: Meibauer (Hg.). Satzmodus zwischen Grammatik und Pragmatik. Tübingen: Niemeyer. (= Linguistische Arbeiten 180).

Altmann, H. (1993). Satzmodus. In: Jacobs/v. Stechow/Sternefeld/Vennemann (Hgg.) Syntax. Ein internationales Handbuch zeitgenössischer Forschung. 1. Halbband. Berlin: Walter de Gruyter. (= KSK 9.1). 1006-1029.

Altmann, H./Batliner, A./Oppenrieder,W. (Hgg.) (1989). Zur Intonation von Modus und Fokus im Deutschen. Tübingen: Niemeyer.

Batliner, A. (1988). Der Exklamativ: Mehr als Aussage oder doch nur mehr oder weniger Aussage? Experimente zur Rolle von Höhe und Position des $\mathrm{F}_{0}$-Gipfels. In: Altmann, H. (Hg.) Intonationsforschungen. Tübingen. (= Linguistische Arbeiten 200). 243-271.

Berman, S. (1994). Wh-Clauses and Quantificational Variability: Two Analyses. Arbeitspapiere des Sonderforschungsbereichs 340 , Nr. 61. Stuttgart/Tübingen.

Bötz, H. (1995). Zur Betonung der w-Phrase in w-Exklamativsätzen. Zulassungsarbeit, Universität Tübingen

d'Avis, F.-J. (2001). Über 'w-Exklamativsätze' im Deutschen. Tübingen: Niemeyer. (= Ph.D. Diss. University of Tübingen 1998).

Dipper, S. (1997). Zur Selektion von Fragesatzkomplementen. Arbeitspapiere des Sonderforschungsbereichs 340, Nr. 122. Stuttgart/Tübingen.

Elliott, D.E. (1974). Toward a Grammar of Exclamatives. Foundations of Language 11. 231-246.

Elliott, D.E. (1971). The Grammar of Emotive and Exclamatory Sentences in English. In: Working Papers in Linguistics No. 8. Ohio State University. viii - 111.

Fries, N. (1988). Ist Pragmatik schwer! - Über sogenannte ,Exklamativsätze“ im Deutschen. Sprache und Pragmatik 3. Lund 1988. 1-18.

Fries, N. (1994). Grammatik, Emotionen und Äußerungsbedeutung. Sprache und Pragmatik 33. Lund 1994. $1-37$.

Grimshaw, J. (1979). Complement Selection and the Lexicon. Linguistic Inquiry 10. 279-326.

Grimshaw, J. (1981). Form, Function and the Language Acquisition Device. In: Baker, C.L./McCarthy, J.J. (eds.). The Logical Problem of Language Acquisition. MIT Press. 165-182.

Groenendijk, J./Stokhof, M. (1982). Semantic Analysis of WH-Complements. Linguistics \& Philosophy 5. $175-233$.

Heim, I. (1994). Interrogative Semantics and Karttunen's Semantics for Know. Manuskript. Erschienen in: Buchalla, R./Mittwoch, A. (eds.). IATL 1. The Proceedings of the Ninth Annual Conference and the Workshop on Discourse of the Israel Association for Theoretical Linguistics. Jerusalem: Academon. 128-144.

Huddleston, R. (1994): The Contrast between Interrogatives and Questions. Journal of Linguistics 30. 411439.

Karttunen, L. (1977). Syntax and Semantics of Questions. Linguistics and Philosophy 1. 3-44.

Lahiri, U. (1991). Embedded Interrogatives and Predicates That Embed Them. Ph.D. Dissertation. MIT Cambridge, Massachusetts.

Oppenrieder, W. (1988). Intonation und Identifikation. Kategorisierungstests zur kontextfreien Identifikation von Satzmodi. In: Altmann, H. (Hg.) Intonationsforschungen. Tübingen. (= Linguistische Arbeiten 200). 153-168.

Rehbock, H. (1997). Eingebettete W- "Exklamativsätze“. Manuskript. 
On the interpretation of wh-clauses in exclamative environments

Rosengren, Inger (1992). Zur Grammatik und Pragmatik der Exklamation. In: Rosengren (Hg.) Satz und Illokution. Bd. I. Tübingen: Niemeyer (= Linguistische Arbeiten 278). 263-306.

Rosengren, I. (1994). Expressive Sentence Types - A Contradiction in Terms. The Case of Exclamation. Sprache und Pragmatik 33. Lund 1994. 38-68.

Rosengren, I. (1997). Expressive Sentence Types - A Contradiction in Terms. The Case of Exclamation. In: Swan, T./ Westvik, O.J. (Hgg.): Modality in Germanic Languages. Historical and Comparative Perspectives. Berlin, New York: Mouton de Gruyter. (= Trends in Linguistics. Studies and Monographs 99).

Schwarz, B. (1993): Gewisse Fragesätze und gewisse Verben, die sie einbetten. Magisterarbeit, Universität Tübingen.

van Os, C. (1989). Aspekte der Intensivierung im Deutschen. Tübingen: Narr.

Wachowicz, K. (1974). On the Syntax and Semantics of Multiple Questions. Ph.D. Dissertation, University of Texas.

Wingert, D. (1996). Zur Intonation und Informationsgliederung von Exklamativsätzen des Deutschen. Magisterarbeit, Universität Tübingen.

Zaefferer, D. (1983). The Semantics of Non-Declaratives: Investigating German Exclamatories. In: Bäuerle/Schwarze/v. Stechow (eds.) (1983). 466-490.

Zaefferer, D. (1984). Frageausdrücke und Fragen im Deutschen. Zu ihrer Syntax, Semantik und Pragmatik. München.

Zanuttini, R./Portner, P. (2000). Exclamative Clauses at the Syntax-Semantics Interface. Ms. Georgetown University. 